\title{
Comparison of Drip and Sprinkler Irrigation Systems for Applying Metam Sodium and Managing Stem Rot on Potato
}

\author{
G. T. Browne, United States Department of Agriculture-Agricultural Research Service (USDA-ARS), Department \\ of Plant Pathology, University of California, Davis 95616; W. R. DeTar, USDA-ARS, 17053 N. Shafter Ave., \\ Shafter, CA 93263; B. L. Sanden, University of California Cooperative Extension, 1031 S. Mount Vernon Ave., \\ Bakersfield 93307; and C. J. Phene (retired), USDA-ARS, WMRL, 9611 S. Riverbend Ave., Parlier, CA 93648
}

\begin{abstract}
Browne, G. T., DeTar, W. R., Sanden, B. L., and Phene, C. J. 2002. Comparison of drip and sprinkler irrigation systems for applying metam sodium and managing stem rot on potato. Plant Dis. $86: 1211-1218$

Drip and sprinkler systems were compared for effectiveness as preplant metam sodium chemigation systems and conduciveness to late-season development of stem rot disease on potato. Sclerotia of Sclerotium rolfsii were used in a bioassay to test efficacy of metam sodium treatments. Drip application of metam sodium (532 liters/ha, 32.8\% a.i.) through lines at $7 \mathrm{~cm}$ of depth in preformed beds (depths from bed top unless stated otherwise) killed all test sclerotia at 15-, 30-, or 46-cm depths. Drip application of the metam sodium through drip lines at 41 or 46 $\mathrm{cm}$ of depth resulted in 0 to 17 or 68 to $80 \%$ survival, respectively, of test sclerotia at $15 \mathrm{~cm}$ of depth; but all the sclerotia at 30 or $46 \mathrm{~cm}$ of depth were killed. Compared with the drip applications, sprinkler chemigation with metam sodium generally treated beds less effectively ( 8 to $100 \%$ of sclerotia survived at $15 \mathrm{~cm}, 62$ to $100 \%$ at 30 or $46 \mathrm{~cm}$ ). On flat ground, drip and sprinkler chemigation (metam sodium, 560 liters/ha) performed equally $(4,37$, and $77 \%$ survival at 15-, 45-, and 75-cm depths, respectively). After potato planting and artificial soil infestation with $S$. rolfsii ( 5 to 6 weeks before harvest), subsurface drip-irrigated plots (line depth of 41 or $46 \mathrm{~cm}$ ) had lower incidence of stem rot disease at harvest (13 to $23 \%$ on tubers) than that in sprinkler plots (56 to $62 \%$ ). The low incidence of disease was associated with relatively dry surface soil. Subsurface drip chemigation with metam sodium in preformed plant beds does not consistently eradicate $S$. rolfsii sclerotia near the upper bed surface but, in an arid climate, it is less conducive than sprinkler irrigation to development of stem rot disease of potato.
\end{abstract}

Additional keywords: chemical, cultural, integrated, Solanum tuberosum

Drip irrigation technology has benefited several vegetable cropping systems $(10,14$, 20,25). Principal advantages of drip over furrow or sprinkler irrigation methods for these crops include increased efficiency of water and fertilizer use and increased yield $(10,14,20,25)$. In addition, use of subsurface drip irrigation has improved management of some plant diseases $(26,29)$. Incidences of lettuce drop caused by Sclerotinia minor and corky root caused by Rhizomonas suberifaciens occurred at a lower rate under subsurface drip irrigation than under conventional furrow irrigation (29). Lettuce downy mildew, however, was

Corresponding author: G. T. Browne

E-mail: gtbrowne@ucdavis.edu

This research was supported in part by the California Potato Research Advisory Board and the University of California Statewide Integrated Pest Management Program.

Accepted for publication 15 May 2002.

Publication no. D-2002-0917-01R

This article is in the public domain and not copyrightable. It may be freely reprinted with customary crediting of the source. The American Phytopathological Society, 2002 not consistently suppressed by the former irrigation method $(26,29)$.

Most commercial potato crops in the western United States are irrigated using sprinklers, but potential benefits of drip irrigation are of interest to many growers. In the southern San Joaquin Valley of California, where most of the state's potatoes are produced, the majority of the crop is planted from early December to early March and harvested from April through early July. The crop requires frequent irrigations totaling 450 to $750 \mathrm{~mm}$ of water, and the soil is subject to excessive nutrient leaching. Longterm problems with availability and cost of water and agricultural contamination of groundwater by leached nitrates have focused attention on improved irrigation practices in California.

Stem rot caused by Sclerotium rolfsii is an important disease of several vegetable crops grown in the San Joaquin Valley, especially potato $(9,30)$. In California, the disease tends to occur near the end of the spring potato season (i.e., late May through July) because the pathogen is most active at relatively warm temperatures (27 to $\left.32^{\circ} \mathrm{C}\right)(30)$. The infections may occur after the potato vines have died from natural senescence or preparation for harvest (30).
Both tubers and stems are affected. Wet or moist periods following dry episodes are particularly conducive to infection by $S$. rolfsii $(5,22)$. In California, stem rot of potato is managed principally by early planting and harvest to avoid the diseaseconducive temperatures and by preplant chemigation with metam sodium to reduce the initial inoculum density. Concerns about human exposure to metam sodium in the increasingly urban environment have raised interest in minimizing off-site drift of the biocide and improving alternative cultural approaches for management of soilborne pathogens.

We hypothesized that subsurface drip irrigation, which can maintain a relatively dry soil surface while supplying crop water requirements, would be less conducive than sprinkler irrigation to stem rot disease. It also was considered that drip systems could be used instead of sprinklers for preplant applications of metam sodium, thereby reducing risk of off-site drift of the biocide. Drip irrigation has been used experimentally on potato in several regions $(3,10-12,19,21,25,27)$, yet comparative effects of drip and conventional sprinkler irrigation on management of potato diseases remain largely unexplored. This study compared effectiveness of sprinkler and drip irrigation systems for applying metam sodium and determined effects of the irrigation systems on incidence and severity of stem and tuber rot caused by $S$. rolfsii on potato. We presented a portion of this work previously (6) and reported on related potato yield effects and engineering aspects of the research elsewhere (10).

\section{MATERIALS AND METHODS}

Irrigation plots. Two concurrent irrigation experiments were conducted each of two years (1994 and 1995) at the Shafter Research and Extension Center near Shafter, CA. In addition to quantifying effects of drip and sprinkler irrigation methods on yield (10), the experiments were designed to determine (i) relative efficacy of drip and sprinkler preplant applications of metam sodium and (ii) comparative effects of drip and sprinkler irrigation practices on incidence and severity of late-season stem and tuber rot caused by $S$. rolfsii. The irrigation plots were situated on Wasco sandy loam and had been planted to cotton in 1992 and potato in 
1993. At field capacity, the soil holds of 0.09 to $0.11 \mathrm{~kg}$ of water per kilogram of dry soil, and the available water capacity is 0.05 to $0.08 \mathrm{~kg}$ of water per kilogram of dry soil; the soil's bulk density averages $1.62 \mathrm{~g} / \mathrm{cm}^{3}$ (W. R. DeTar and B. L. Sanden, unpublished). Experimental plots involving metam sodium and $S$. rolfsii treatments were nested within or superimposed on the irrigation plots, as described below.

In one of the 1994 tests, hereafter referred to as a small-plot experiment, all plots had single-row beds on $0.8-\mathrm{m}$ centers, and the treatments included (i) nearsurface drip irrigation with drip lines installed within $7 \mathrm{~cm}$ beneath the bed tops, (ii) subsurface drip irrigation with the lines buried $46 \mathrm{~cm}$ beneath the bed tops, and (iii) sprinkler irrigation. After the beds settled, the near-surface drip tubing became exposed at many points along the beds. Each irrigation treatment was imposed on five 14.9 - by $4.6-\mathrm{m}$ replicate plots in randomized complete blocks. The drip lines ( $\mathrm{T}$ tape; T-systems Intl., San Diego, CA) consisted of 16-mm-inside-diameter drip tape with emitters spaced $30.5 \mathrm{~cm}$ apart. At 54 $\mathrm{kPa}$, the emitter discharge rate was 1 liter/h. Each sprinkler plot was irrigated from two supply lines placed on the 14.6$\mathrm{m}$ plot boundaries. The sprinklers (300 series part-circle stream rotor; The Toro Co., Riverside, CA) were mounted on the lines at plot corners and at 4.9-m intervals. At $238 \mathrm{kPa}$, they applied water at 18.1 $\mathrm{mm} / \mathrm{h}$.

In the other 1994 test, hereafter referred to as a large-plot experiment, irrigation treatments included (i) subsurface drip irrigation with one drip line placed $41 \mathrm{~cm}$ beneath the top of every single-row bed on $0.8-\mathrm{m}$ centers, (ii) subsurface drip irrigation with one drip line centered $41 \mathrm{~cm}$ beneath the top of each double-row bed on 1.6-m centers, and (iii) conventional sprinkler irrigation with single-row beds on 0.8 $\mathrm{m}$ centers. Each irrigation treatment was imposed on seven 12.9- by 27.4-m plots in randomized complete blocks. The drip lines (Netafim Irrigation, Inc., Fresno, CA) were installed for potato in 1993 and consisted of semihard hose (13-mm inside diameter) with in-line labyrinth emitters spaced $46 \mathrm{~cm}$ apart (emitter discharge rate 2.5 liters $/ \mathrm{h}$ at $170 \mathrm{kPa}$ ). Each sprinkler plot was irrigated from two supply lines placed along the 27.4-m plot boundaries. Each of the lines had sprinklers with rotary impact heads (part-circle adjustable; Rain Bird Sprinkler Mfg. Corp., Glendora, CA) mounted at plot corners and at 9.1-m intervals. At operating pressure $(306 \mathrm{kPa})$, the sprinklers applied water at $9.2 \mathrm{~mm} / \mathrm{h}$. Distribution uniformity (DU) of water application in the sprinkler plots was $66 \%$, which was identical to the average DU reported for commercial sprinkler systems in the San Joaquin Valley (18). For sprinklers, DU is determined by measuring water amounts delivered to catch containers placed on a grid in the irrigated area; DU equals the average of the lowest $25 \%$ of amounts delivered to containers divided by the overall average of amounts delivered (15).

The small- and large-plot irrigation experiments were repeated in 1995. The repeat small-plot experiment had six replicate plots per irrigation treatment in randomized complete blocks. The irrigation plots measured 6.5 by $9.1 \mathrm{~m}$, and new drip tape with the same specifications as in 1994 was installed. The small-plot sprinkler water application rate was $17.3 \mathrm{~mm} / \mathrm{h}$ with a DU of $78 \%$. The repeat large-plot experiment was confined to six of the seven replicate blocks that were used in 1994, and the drip lines used in 1994 remained in place for 1995 .

Preplant applications of metam sodium. After preparing the plant beds in 1994 and 1995, the irrigation systems and plots described above were used for preplant chemigation tests with metam sodium. In the small-plot chemigation experiments, the irrigation plots were split evenly to accommodate randomly assigned subplot treatments of metam sodium (532 liters/ha, $32.8 \%$ a.i. liquid formulation, continuously injected in $63 \mathrm{~mm}$ of water) and a control (63 $\mathrm{mm}$ of water alone). The small-plot chemigations were applied on 27 to 28 January 1994 and 3 February 1995. In the large-plot chemigation experiments, a nonchemical control was not feasible, and all irrigation plots received metam sodium (532 liters/ha in $63 \mathrm{~mm}$ of water). The large-plot chemigations occurred on 24 to 25 January 1994 and 2 February 1995. Efficacy of the large- and small-plot chemigations was determined with a bioassay, as described below.

An additional test of drip and sprinkler applications of metam sodium was conducted in a commercial field near Lamont, $\mathrm{CA}$ on flat ground before shaping plant beds. Treatments of metam sodium (560 liters/ha, $32.8 \%$ a.i. liquid formulation, in $76 \mathrm{~mm}$ of water) and a control (76 $\mathrm{mm}$ of water alone) were applied either by conventional sprinklers or by a surface drip system. Each treatment combination was applied to three replicate 13.7 - by $27.4-\mathrm{m}$ plots in a completely randomized design on 18 January 1995. Prior to treatment, the plots were cultivated with a harrow to produce a loose, smooth soil surface. Drip emitters were spaced $0.3 \mathrm{~m}$ apart along and between drip lines, which afforded nearly continuous wetting of the soil area. The drip system application rate was 17.8 $\mathrm{mm} / \mathrm{h}$. Sprinklers were spaced $9.1 \mathrm{~m}$ apart along lines and $13.7 \mathrm{~m}$ apart between lines. The sprinkler system application rate was $5.8 \mathrm{~mm} / \mathrm{h}$. Efficacy of the treatments was assessed with the bioassay described below.

Bioassays to determine efficacy of metam sodium treatments. Sclerotia of $S$. rolfsii were used to assay the effectiveness of the metam sodium treatments in the Shafter and Lamont plots. The sclerotia were produced on barley seed in 480-ml jars. In each jar, $30 \mathrm{ml}$ of distilled water was added to $20 \mathrm{ml}$ of dry barley seed. The medium was autoclaved on 2 or 3 successive days for $1 \mathrm{~h}$ at $121^{\circ} \mathrm{C}$, inoculated with a mycelial plug from an acidified potato dextrose agar culture of the fungus, and incubated in darkness or subdued light for 1 month at 20 to $25^{\circ} \mathrm{C}$. The sclerotia were separated from barley grains by dry sieving and mixed with sterile Wasco sandy loam $(1: 5, \mathrm{vol} / \mathrm{vol})$. The infested soil was packaged into close-fitting nylon bags $(10 \mathrm{ml}$ per bag), which in turn were attached to nylon cords. Once loaded, each cord had a single bioassay bag or bags attached at one to three positions along its length according to treatment monitoring requirements described below.

The loaded cords were placed in the chemigation plots 1 day before applying the biocide. In the small-plot experiments at Shafter, two cords of bioassay bags were placed in each replicate metam sodium and water-control subplot. In the large-plot tests, two cords were placed in each metam sodium plot (there was no control). In the monitored plots, one of the cords in each bioassay cord pair was lowered into a freshly dug 8-cm-diameter vertical hole positioned in a plant bed, in line with a future plant row (in the bed center for single-row beds, $41 \mathrm{~cm}$ off the bed center for double-row beds); the other cord of each pair was positioned under a furrow adjacent to the monitored plant bed. The excavated soil was returned to the vertical holes around the cords and lightly tamped in the process, leaving bioassay bags buried beneath the bed tops at depths of 15 and 46 $\mathrm{cm}$ (1994) or 15, 30, and $46 \mathrm{~cm}$ (1995) and beneath the furrow bottoms at a depth of $15 \mathrm{~cm}$. Depending on the experiment and whether plant-bed or furrow locations were being monitored, the cords were situated 0 to $1.6 \mathrm{~m}$ from the center of the chemigation plots.

For bioassays at Lamont, two cords with bioassay bags were placed in each 13.7-by27.4-m plot. One cord of each pair was placed within $1.5 \mathrm{~m}$ of the plot center, and the other was placed $7 \mathrm{~m}$ away from the plot center and $1.5 \mathrm{~m}$ from one of the long plot boundaries. All of the cords were buried within 8-cm-diameter vertical holes as occurred at Shafter, except that each cord at Lamont had single bioassay bags buried at 15,45 , and $75 \mathrm{~cm}$ beneath the soil surface.

For each test, the buried bags were retrieved 3 weeks after metam sodium application, and the sclerotia were tested for viability. Ten sclerotia were randomly sampled from each bag, surface sterilized for $2 \mathrm{~min}$ in $0.5 \% \mathrm{NaOCl}$, rinsed in sterile water, and cultured on acidified potato dextrose agar. Germination of the sclerotia was used as the criterion of viability. 
Potato culture. Potato plants were grown for stem and tuber rot evaluations in the Shafter irrigation-chemigation plots described above. In preparation, composted manure and gypsum were incorporated (each at $11,350 \mathrm{~kg} / \mathrm{ha}$ ) in all Shafter plots during November and December (in 1994 and 1995). Certified potato "seed" tuber pieces were planted in the plots 3.5 to 4.0 weeks after the metam sodium treatments were applied. Cultivars Russet Norkotah and White Rose were assigned randomly to splits of irrigation plots in the large-plot experiments, whereas only White Rose was planted in small-plot experiments. Plant spacing and culture were representative of local industry practice.

Fertilization and irrigation amounts and schedules were chosen in accordance with the appropriate commercial practice for each irrigation system, as described previously (10). All irrigations and all post-plant applications of fertilizer were made to plots through the resident sprinkler and drip systems. Sprinkler irrigations usually were applied two times per week, while drip irrigations typically occurred daily. As full plant canopies developed, sprinklers typically applied 15 to $30 \mathrm{~mm}$ of water per irrigation, and drip systems typically applied 2 to $10 \mathrm{~mm}$ per irrigation. Irrigation control was automated, and amounts of water to apply were determined separately for each treatment according to class " $\mathrm{A}$ " evaporation pan measurements, crop-pan coefficients, irrigation system efficiencies, and confirmatory soil moisture monitoring (10). The water application amounts were adjusted as required according to tensiometer and neutron probe readings in the irrigation plots. Total irrigation water amounts applied in 1994 (and 1995) to small-plot sprinkler, near-surface drip, and subsurface drip plots were 648 (631), 475 (461), and 488 (432) $\mathrm{mm}$, respectively. The water amounts applied to the large-plot sprinkler, single-row subdrip, and double-row subdrip plots in 1994 (and 1995) were 696 (569), 472 (371), and 566 (422) $\mathrm{mm}$, respectively. Tensiometer readings at the 46$\mathrm{cm}$ depth in plant beds usually were maintained between 5 and $15 \mathrm{kPa}$ tension in drip-irrigated plots and between 5 and 35 $\mathrm{kPa}$ tension in sprinkler-irrigated plots.

Effects of irrigation method on stem and tuber rot. Noninfested (control) subplots and subplots artificially infested with $S$. rolfsii were established within both of the small-plot experiments (1994 and 1995) and one of the large-plot experiments (1995) at Shafter. Each subplot was $1.6 \mathrm{~m}$ (two plant rows) wide and $1.5 \mathrm{~m}$ long and included from 11 to 23 (mean = 16) potato plants. The subplots were paired (one inoculated and one noninoculated) near the center of each irrigation plot in the middle two plant rows. A 1.5-m-long buffer area separated the noninfested and infested subplots of each pair and was used for sampling to determine soil water con- tent (described below). In the small-plot experiments, one bed in each subplot had received preplant metam sodium; the other bed had served as a water control. In the large-plot experiment, one row in each soil infestation subplot had cv. Russet Norkotah, and the other had White Rose.

The inoculum of $S$. rolfsii for the infested subplots was prepared on barley seed as described above for the metam sodium test bioassays, except that, for the stem rot tests, sclerotia were not separated from colonized grains. The $S$. rolfsii and control subplots were inoculated on 25 May (1994 small-plot experiment) or 25 and 26 May (1995 small- and large-plot experiments). In each case, $10 \mathrm{ml}$ of the colonized grain and sclerotia was mixed into soil at a depth of 0 to $4 \mathrm{~cm}$ and 4 to 6 $\mathrm{cm}$ away from the main stem of each plant in the subplots. Controls were treated in the same way, except with sterile grain.

At 4 to 5 weeks after soil infestation, incidence and severity of stem rot disease were determined for each noninfested and $S$. rolfsii-infested subplot. The main stem axis of each plant was lifted carefully and exposed with a hand-held digging fork. Each main stem was examined for necrosis combined with signs of stem rot disease ( $S$. rolfsii mycelium or sclerotia). All tubers in the subplots were dug with the fork and inspected individually for incidence of the pathogen as indicated by $S$. rolfsii mycelium on the tuber surface. Severity of the disease was graded on each tuber according to a visual estimate of the percentage of the tuber surface covered by the mycelium as follows: $0=$ no apparent $S$. rolfsii mycelium, $1=$ up to $25 \%$ covered, $2=26$ to $50 \%$ covered, $3=51$ to $75 \%$ covered, and $4=76$ to $100 \%$ covered.

Tubers harvested for yield evaluations at Shafter (10) also were observed for $S$. rolfsii mycelium associated with stem rot disease. In the large-plot experiments, tubers from two rows (each $27 \mathrm{~m}$ long) were harvested and inspected per irrigation method-cultivar subplot. In the small-plot tests, the tubers from one row (each 9 to 15 $\mathrm{m}$ long, depending on year) were harvested and inspected per replicate irrigation method-metam sodium subplot. All of these harvested rows were outside of the areas of artificially infested $S$. rolfsii or serving as a noninfested control. The tubers were inspected visually as they passed on a grading platform.

Soil temperature and moisture monitoring. In 1995, CR-10 microloggers (Campbell Scientific Inc. [CSI], Logan, UT) were equipped with temperature probes (107B; CSI) to measure soil temperature at $15 \mathrm{~cm}$ beneath the top of plant beds at 30-min intervals. Two plots were monitored per irrigation treatment in the large-plot experiment, and one plot was monitored per treatment in the small-plot experiment. In addition, soil samples were collected to determine soil water content (kilograms of water per kilogram of ovendried soil) at a depth of 0 to $4 \mathrm{~cm}$ in each irrigation plot. The samples (each weighing approximately $0.2 \mathrm{~kg}$ ) were collected two to three times per week in the buffer area between noninfested and $S$. rolfsiiinfested subplots.

Data analyses. For each experiment, analysis of variance (ANOVA) was completed using the MIXED procedure of SAS software (releases 7.00 and 8.00; SAS, Cary, NC). The ANOVAs for metam sodium experiments were conducted separately for sclerotia survival percentages from water-control and metam sodium plots. Those from control plots ranged mostly from 80 to $100 \%$ and were transformed by subtraction from 100 followed by conversion to square roots before ANOVA. The survival percentages from metam sodium-treated plots ranged from 0 to $100 \%$ and were arcsine transformed before ANOVA. For data from both control and metam sodium plots, ANOVA was conducted according to the split-plot design (main plots were chemigation plots, subplots were the positions of test sclerotia in soil). Nontransformed mean survival percentages are presented in tables with mean separation letters assigned according to $95 \%$ confidence intervals for the corresponding transformed data.

Data from the stem rot experiments were analyzed without transformation according to the split-plot designs. The main plot factor was always irrigation system, and the subplot factors, depending on experiment, included preplant metam sodium treatment, potato cultivar, and date of soil moisture sampling. Disease data from the S. rolfsii-infested subplots were analyzed separately from data from noninfested control subplots, because the latter had no stem rot disease. The CORR procedure of SAS was applied to data from Shafter to test for selected correlations among the variables of plant and tuber counts per plot, surface soil water content, and incidence and severity of stem and tuber infection by S. rolfsii. For all experiments, least square means were calculated and separated according to $95 \%$ confidence intervals where appropriate.

\section{RESULTS}

Bioassays to determine efficacy of metam sodium treatments. In watertreated control subplots of 1994 and 1995 small-plot metam sodium experiments at Shafter, mean survival of the $S$. rolfsii sclerotia buried in bags ranged from 82 to $100 \%$ and was not affected by year, position in soil, or method of water application $(P=0.24$ to 0.86$)$. In metam sodiumtreated plots of these experiments, however, the survival percentages were strongly affected by interaction between irrigation (chemigation) system and position in soil $(P<0.0001)$. In the biocidetreated plots, main and interactive effects 
of year on survival percentages were insignificant $(P=0.23$ to 0.94$)$, but the means were separated within years, due to lack of sclerotia placement at the $30-\mathrm{cm}$ soil depth in 1994 (Table 1). Sprinkler application of metam sodium in the small-plot experiments killed most $S$. rolfsii test sclerotia at the $15-\mathrm{cm}$ depth in plant beds (survival 8 to 20\%, 1994 and 1995; Table 1), but most of those at the 30- and 46-cm depths in plant beds survived (survival 62 to 100\%). Sprin- kler-applied metam sodium killed all test sclerotia under furrows. On the other hand, drip application of metam sodium through the near-surface tape killed all test sclerotia placed in beds but did not reduce the survival percentages under furrows (Table 1). Subsurface chemigation through the drip tape was not effective at the $15-\mathrm{cm}$ depth in beds (survival 68 to $80 \%$ ) or under furrows (98 to $100 \%$ ), but it eradicated sclerotia at the 30- and 46-cm depths in beds.

Table 1. Effects of metam sodium application method on survival of bioassay sclerotia of Sclerotium rolfsii in soil of small-plot experiments at Shafter

\begin{tabular}{|c|c|c|c|c|}
\hline \multirow[b]{2}{*}{ Application method ${ }^{z}$} & \multicolumn{2}{|c|}{ Placement of sclerotia ${ }^{x}$} & \multicolumn{2}{|c|}{$\begin{array}{c}\text { Sclerotia survival } \\
(\%)^{\mathrm{y}}\end{array}$} \\
\hline & Horizontal location & Depth from soil surface $(\mathrm{cm})$ & 1994 & 1995 \\
\hline \multirow{4}{*}{ Sprinkler } & Bed & 15 & $20 \mathrm{~b}$ & $8 \mathrm{c}$ \\
\hline & Bed & 30 & $\ldots$ & $62 \mathrm{~b}$ \\
\hline & Bed & 46 & $100 \mathrm{a}$ & $83 \mathrm{ab}$ \\
\hline & Furrow & 15 & $0 \mathrm{~b}$ & $0 \mathrm{c}$ \\
\hline \multirow[t]{4}{*}{ Near-surface drip } & Bed & 15 & $0 \mathrm{~b}$ & $0 \mathrm{c}$ \\
\hline & Bed & 30 & ... & $0 \mathrm{c}$ \\
\hline & Bed & 46 & $0 \mathrm{~b}$ & $0 \mathrm{c}$ \\
\hline & Furrow & 15 & $100 \mathrm{a}$ & $82 \mathrm{ab}$ \\
\hline \multirow[t]{4}{*}{ Subsurface drip } & Bed & 15 & $80 \mathrm{a}$ & $68 \mathrm{ab}$ \\
\hline & Bed & 30 & $\ldots$ & $0 \mathrm{c}$ \\
\hline & Bed & 46 & $0 \mathrm{~b}$ & $0 \mathrm{c}$ \\
\hline & Furrow & 15 & $100 \mathrm{a}$ & $98 \mathrm{a}$ \\
\hline
\end{tabular}

${ }^{\mathrm{x}}$ The sclerotia were produced on and extracted from barley seed before placement in soil at positions indicated.

${ }^{y}$ Viability of the sclerotia was determined on acidified potato dextrose agar. Values are nontransformed least square means, each from five (1994) or six (1995) replicate samples of 10 sclerotia; ... indicates positions not monitored in 1994. The means within a column and without letters in common had corresponding arcsine-transformed values that differed significantly according to $95 \%$ confidence intervals. Mean survival of S. rolfsii sclerotia in control plots was 82 to $100 \%$.

${ }^{\mathrm{z}}$ Sprinklers were part-circle, stream rotor type. Drip tape was buried at 0 to $7 \mathrm{~cm}$ beneath the upper surface of preformed plant beds (near-surface drip) or $46 \mathrm{~cm}$ beneath the surface (subsurface drip). Metam sodium (32.7\%, 532 liters/ha) was applied through the irrigation systems in $63 \mathrm{~mm}$ of water after formation of plant beds. Controls received $63 \mathrm{~mm}$ of water alone.

Table 2. Effects of metam sodium application method on survival of bioassay sclerotia of Sclerotium rolfsii in soil of large-plot experiments at Shafter

\begin{tabular}{|c|c|c|c|c|}
\hline \multirow[b]{2}{*}{ Application method ${ }^{z}$} & \multicolumn{2}{|c|}{ Placement of sclerotia $^{x}$} & \multicolumn{2}{|c|}{$\begin{array}{c}\text { Sclerotia surviva } \\
(\%)^{\mathrm{y}}\end{array}$} \\
\hline & Horizontal location & Depth from soil surface $(\mathrm{cm})$ & 1994 & 1995 \\
\hline \multirow[t]{4}{*}{ Sprinkler } & Bed & 15 & $86 \mathrm{a}$ & $100 \mathrm{a}$ \\
\hline & Bed & 30 & & $97 \mathrm{a}$ \\
\hline & Bed & 46 & $83 \mathrm{a}$ & $83 \mathrm{a}$ \\
\hline & Furrow & 15 & $0 \mathrm{~b}$ & $0 \mathrm{~b}$ \\
\hline \multicolumn{5}{|l|}{ Subsurface drip } \\
\hline \multirow[t]{4}{*}{ Single row } & Bed & 15 & $0 \mathrm{~b}$ & $17 \mathrm{~b}$ \\
\hline & Bed & 30 & $\ldots$ & $0 \mathrm{~b}$ \\
\hline & Bed & 46 & $0 \mathrm{~b}$ & $0 \mathrm{~b}$ \\
\hline & Furrow & 15 & $100 \mathrm{a}$ & $82 \mathrm{a}$ \\
\hline \multirow[t]{4}{*}{ Double row } & Bed & 15 & 96 a & $97 \mathrm{a}$ \\
\hline & Bed & 30 & $\ldots$ & $100 \mathrm{a}$ \\
\hline & Bed & 46 & $33 \mathrm{~b}$ & $80 \mathrm{a}$ \\
\hline & Furrow & 15 & $93 \mathrm{a}$ & $100 \mathrm{a}$ \\
\hline
\end{tabular}

$\overline{\mathrm{x}}$ The sclerotia were produced on and extracted from barley seed before placement in soil at positions indicated.

${ }^{y}$ Viability of the sclerotia was determined on acidified potato dextrose agar. Values are nontransformed least square means, each based on seven (1994) or six (1995) replicate samples of 10 sclerotia; ... indicates positions not monitored in 1994. The means within a column and without letters in common had corresponding arcsine-transformed values that differed significantly according to $95 \%$ confidence intervals.

${ }^{\mathrm{z}}$ Sprinklers were part-circle adjustable, rotary impact. Drip tubing was buried at $41 \mathrm{~cm}$ beneath the top of preformed single- or double-row plant beds (subsurface drip single-row and subsurface drip double-row, respectively). Metam sodium $(32.7 \%, 532$ liters/ha) was applied through the irrigation systems in $63 \mathrm{~mm}$ of water after formation of plant beds.
As in the small-plot tests, mean survival percentages for $S$. rolfsii bioassay sclerotia in the large-plot metam sodium tests were strongly affected by interaction between irrigation (chemigation) system and position in soil $(P<0.0001)$. Main and interactive effects of year on sclerotia survival were small or insignificant $(P=0.13$ to 0.35$)$. In the sprinkler-treated plots, most $S$. rolfsii test sclerotia placed in plant beds survived metam sodium application (survival 83 to 100\%; Table 2), but those placed $15 \mathrm{~cm}$ under the furrows were eradicated. Conversely, in single-row subsurface drip plots treated with metam sodium, most bioassay sclerotia in the beds were killed (survival 0 to $17 \%$ ), while most of those placed under furrows survived (82 to $100 \%$ ). Doublerow subsurface drip applications of metam sodium generally were ineffective (survival 33 to $100 \%$; Table 2).

In water-treated control plots of the Lamont metam sodium experiment, 92 to $100 \%$ of bioassay sclerotia survived, and there was no effect of application method (sprinkler or surface drip) or soil position (15-, 45-, or 75-cm depths) on survival ( $P$ $=0.33$ to 0.97 ). In the Lamont plots treated with metam sodium, application method had no significant main or interactive effect on survival of test sclerotia $(P=0.27$ to 0.86$)$, but the depth in soil significantly influenced the survival $(P=0.0004)$. Although most of the sclerotia were killed at 15- and 45-cm depths, most of those at 75$\mathrm{cm}$ depth survived (Table 3 ).

Effect of irrigation method on stem and tuber rot. In the three Shafter irrigation experiments that involved soil infestation with S. rolfsii (1994 and 1995 smallplot tests; 1995 large-plot test), potato plants and tubers in the noninfested control subplots had no symptoms of stem rot disease and no signs of the pathogen. Simi-

Table 3. Effect of depth in soil on survival of bioassay sclerotia of Sclerotium rolfsii following application of metam sodium at Lamont

\begin{tabular}{|c|c|}
\hline $\begin{array}{l}\text { Depth of test sclerotia } \\
\text { in soil }(\mathbf{c m})\end{array}$ & $\begin{array}{l}\text { Sclerotia survival } \\
(\%)^{\mathrm{z}}\end{array}$ \\
\hline $\begin{array}{l}15 \\
45 \\
75\end{array}$ & $\begin{array}{r}4 \mathrm{~b} \\
37 \mathrm{~b} \\
77 \mathrm{a}\end{array}$ \\
\hline $\begin{array}{l}\text { Sclerotia were prod } \\
\text { from barley seed bef } \\
\text { positions indicated. } \\
560 \text { liters/ha) was a } \\
\text { and drip irrigation sys } \\
\text { to flat ground that ha } \\
\text { rowed) surface. Contr } \\
\text { of water alone. Viabi } \\
\text { determined on acidifi } \\
\text { Values are nontransfo } \\
\text { on six replicate san } \\
\text { treated plots and thre } \\
\text { plots) of } 20 \text { scleroti } \\
\text { column and without } \\
\text { corresponding arcsine } \\
\text { differed significantly } \\
\text { dence intervals. Mea } \\
\text { sclerotia in control pl }\end{array}$ & $\begin{array}{l}\text { on and extracted } \\
\text { placement in soil at } \\
\text { am sodium } 32.7 \% \text {, } \\
\text { d through sprinkler } \\
\text { s in } 76 \mathrm{~mm} \text { of water } \\
\text { smooth, loose (har- } \\
\text { lots received } 76 \mathrm{~mm} \\
\text { of the sclerotia was } \\
\text { otato dextrose agar. } \\
\text { d means, each based } \\
\text { s (three from drip- } \\
\text { om sprinkler-treated } \\
\text { The means within a } \\
\text { ers in common had } \\
\text { nsformed values that } \\
\text { ording to } 95 \% \text { confi- } \\
\text { urvival of } S \text {. rolfsii } \\
\text { vas } 92 \text { to } 100 \% \text {. }\end{array}$ \\
\hline
\end{tabular}


larly, no mycelium of $S$. rolfsii was detected on tubers harvested for yield evaluations from the areas outside of stem rot disease plots in Shafter irrigation experiments (1994 and 1995 small- and largeplot tests). In the subplots that were artificially infested with $S$. rolfsii, however, mycelial growth of the pathogen often became evident where the sites of infestation were moistened by irrigation.

Incidence of stem infection by $S$. rolfsii in the infested subplots of small-plot experiments (1994 and 1995; Table 4) exhibited significant interaction between irrigation method and year $(P=0.005)$. Within both years, however, the infested subplots irrigated by subsurface drip had significantly lower incidence of stem infection by S. rolfsii (12 to $25 \%$; Table 4) compared with those irrigated by near-surface drip or sprinklers (53 to $82 \%$ ). There was a small effect of preplant metam sodium treatment on the incidence of stem infection in the infested subplots $(P=0.036)$. The incidence was lower on the sides of infested subplots that had received metam sodium before planting (mean 50\%) than on the sides of the water-control treatment (mean $59 \%$ ), but the $95 \%$ confidence intervals for the two means overlapped. There was no significant interaction of metam sodium with other treatment factors $(P=0.49$ to $0.89)$. The number of potato plants per infested subplot (regardless of health status) was not affected significantly by irrigation method or interactions involving irrigation method ( $P=0.39$ to 0.79 ).

Incidence and severity of tuber infections caused by $S$. rolfsii in the infested subplots of small-plot experiments were affected by significant interaction between irrigation method and year $(P=0.002$ to $0.015)$. The tuber disease data, however, did not exhibit significant main or interactive effects from preplant metam sodium treatment $(P=0.16$ to 0.98$)$. Infested subplots irrigated by subsurface drip consis- tently had much lower incidence of tuber infection (means of 17 and $23 \%$ in 1994 and 1995, respectively; Table 4) compared with those irrigated by sprinklers (means 61 to $62 \%$ ). Furthermore, the subplots with subsurface drip consistently had lower tuber disease severity scores (means of 0.2 and 0.3 in 1994 and 1995, respectively) compared with those under sprinkler irrigation (1.0, both years). Tuber disease responses resulting under near-surface drip were less consistent than those for subsurface drip and sprinkler irrigation. For example, in 1994, near-surface drip-irrigated plots had relatively high incidence of tuber infection $(53 \%)$ and tuber disease severity scores (mean 0.8 ) caused by $S$. rolfsii; these values were statistically equivalent to those from sprinkler plots and significantly higher than those from subsurface drip plots (Table 4). In 1995, however, nearsurface drip subplots infested with $S$. rolfsii had significantly less incidence of tuber infection by the pathogen $(28 \%)$ and a lower mean tuber disease severity score (0.4) compared with the sprinkler plots.

There were 72 to 141 tubers per $S$. rolfsii-infested subplot in the small-plot experiments (range for 1994 and 1995). The number of tubers per subplot was affected by year $(P<0.0001)$ and irrigation method $(P=0.038)$. There were significantly fewer tubers per infested subplot in 1994 (mean 89) than in 1995 (mean 113) $(P=0.05)$, but the $95 \%$ confidence intervals overlapped for the mean number of tubers per infested subplot in sprinkler, near-surface drip, and subsurface drip treatments (93, 108, and 103, respectively). There were small but significant negative correlations between the number of tubers in the infested subplots and corresponding incidence of tuber infection (Pearson correlation coefficient $r=-0.36, P=0.04)$ and between the number of tubers and the tuber disease severity scores $(r=-0.41, P=$ 0.02 ).
In the $S$. rolfsii-infested subplots of the large-plot experiment, irrigation method had highly significant effects on the stem and tuber disease parameters $(P<0.0001$; Table 4). Single- and double-row subsurface drip irrigation both resulted in much lower incidences of stem and tuber infection (11 to $21 \%$; Table 4) compared with the incidences under sprinkler irrigation (56 to 59\%). Furthermore, both of the subsurface drip-irrigation treatments had smaller tuber disease severity scores $(0.2$ to 0.3 ; Table 4), compared with the sprinkler irrigation treatment (1.2). In the same infested subplots, potato cultivar did not affect incidence of stem infection $(P=$ $0.29)$ and had a relatively small effect on incidence of tuber infection $(P=0.08)$. Severity scores for tuber infection were affected by potato cultivar $(P=0.01)$, but the $95 \%$ confidence intervals overlapped for mean tuber disease severity scores on Russet Norkotah and White Rose (0.7 and 0.4 , respectively). There was no significant interaction between irrigation method and potato cultivar for the stem or tuber disease parameters $(P=0.23$ to 0.85$)$.

Irrigation method did not significantly affect the number of plants or tubers (regardless of health status) in the infested subplots of the 1995 large-plot experiment ( $P=0.11$ and 0.16 , respectively), but subplot rows planted to Russet Norkotah had fewer plants and tubers (means 7.1 and 31.9, respectively) than those planted to White Rose (8.7 and 46.9, respectively) $(P=0.05)$. The plant and tuber counts did not exhibit significant cultivar by irrigation method interaction ( $P=0.90$ and 0.45 , respectively).

Effects of irrigation method on soil temperature and moisture content. From the time of soil infestation with $S$. rolfsii to the time of tuber harvest and disease assessment, average daily soil temperatures at $15 \mathrm{~cm}$ of depth in plant beds of the 1995 small-plot experiment increased from 19 to $23^{\circ} \mathrm{C}$ (averaged across irrigation treat-

Table 4. Effect of irrigation method on incidence and severity of stem rot disease and amount of moisture in surface soil ${ }^{\mathrm{x}}$

\begin{tabular}{|c|c|c|c|c|c|}
\hline \multirow[b]{2}{*}{ Year, experiment } & \multirow[b]{2}{*}{ Irrigation method } & \multicolumn{2}{|c|}{ Incidence of infection (\%) } & \multirow[b]{2}{*}{ Disease severity $^{y}$} & \multirow[b]{2}{*}{ Mean water $\left(\mathrm{kg} \mathrm{kg}^{-1}\right)^{\mathrm{z}}$} \\
\hline & & Main stems & Tubers & & \\
\hline \multicolumn{6}{|l|}{1994} \\
\hline \multirow{3}{*}{ Small plot } & Sprinkler & $82 \mathrm{a}$ & $61 \mathrm{a}$ & $1.0 \mathrm{a}$ & $0.066 \mathrm{a}$ \\
\hline & Near-surface drip & $79 \mathrm{a}$ & $53 \mathrm{a}$ & $0.8 \mathrm{a}$ & $0.074 \mathrm{a}$ \\
\hline & Subsurface drip & $12 \mathrm{~b}$ & $17 \mathrm{~b}$ & $0.2 \mathrm{~b}$ & $0.018 \mathrm{~b}$ \\
\hline \multicolumn{6}{|l|}{1995} \\
\hline \multirow[t]{3}{*}{ Small plot } & Sprinkler & $76 \mathrm{a}$ & $62 \mathrm{a}$ & $1.0 \mathrm{a}$ & $0.055 \mathrm{a}$ \\
\hline & Near-surface drip & $53 \mathrm{a}$ & $28 \mathrm{~b}$ & $0.4 \mathrm{~b}$ & $0.061 \mathrm{a}$ \\
\hline & Subsurface drip & $25 \mathrm{~b}$ & $23 \mathrm{~b}$ & $0.3 \mathrm{~b}$ & $0.039 \mathrm{~b}$ \\
\hline \multirow[t]{3}{*}{ Large plot } & Sprinkler & $59 \mathrm{a}$ & $56 \mathrm{a}$ & $1.2 \mathrm{a}$ & $0.042 \mathrm{a}$ \\
\hline & Subsurface drip, single row & $21 \mathrm{~b}$ & $13 \mathrm{~b}$ & $0.2 \mathrm{~b}$ & $0.031 \mathrm{ab}$ \\
\hline & Subsurface drip, double row & $11 \mathrm{~b}$ & $15 \mathrm{~b}$ & $0.3 \mathrm{~b}$ & $0.025 \mathrm{~b}$ \\
\hline
\end{tabular}

${ }^{\mathrm{x}}$ Disease data are from subplots infested with Sclerotium rolfsii; noninfested control subplots had no incidence of the disease (data not shown). Values are least square means from five to seven replicate plots per treatment, depending on year and experiment. Per replicate subplot, there were 11 to 23 potato plants and 55 to 141 tubers. Means within a column and experiment-year combination and without letters in common differ significantly according to $95 \%$ confidence intervals.

y Tuber disease severity scores were based on the percentage of the tuber surface covered by the mycelium: $0=$ no apparent $S$. rolfsii mycelium, $1=$ up to $25 \%$ covered, $2=26$ to $50 \%$ covered, $3=51$ to $75 \%$ covered, and $4=76$ to $100 \%$ covered.

${ }^{\mathrm{z}}$ Mean surface soil water contents of soil samples collected from 0- to 4-cm depths in plant beds. The values are averages from samples collected two to three times per week beside each replicate $S$. rolfsii subplot during the stem rot experiments. 
ments). The daily mean soil temperature averaged $2^{\circ} \mathrm{C}$ cooler under sprinklers than under subsurface or near-surface drip irrigation. During the same period in the 1995 large-plot experiment, the average daily soil temperature increased from 19 to $24^{\circ} \mathrm{C}$ and averaged $1{ }^{\circ} \mathrm{C}$ warmer under sprinklers than under single- and double-row drip treatments. During the 1994 and 1995 stem rot tests, soil water content at 0 to $4 \mathrm{~cm}$ of depth in plant beds was often higher in sprinkler or near-surface drip-irrigated plots than in subsurface drip-irrigated plots (Fig. 1 A-C; Table 4). The mean soil water contents, calculated for individual irrigation plots (i.e., the within-plot averages for the period between soil infestation and disease assessment) were correlated positively with the corresponding plot incidences of stem infection within infested subplots of each of the three stem rot experiments ( $r=0.65$ to $0.92, P=0.0037$ to $<0.0001)$ and across all three of the tests (data combined, $r=0.82, P<0.0001$, Fig. 2A). The mean soil water contents also were correlated positively with tuber infection incidences within the 1994 small-plot

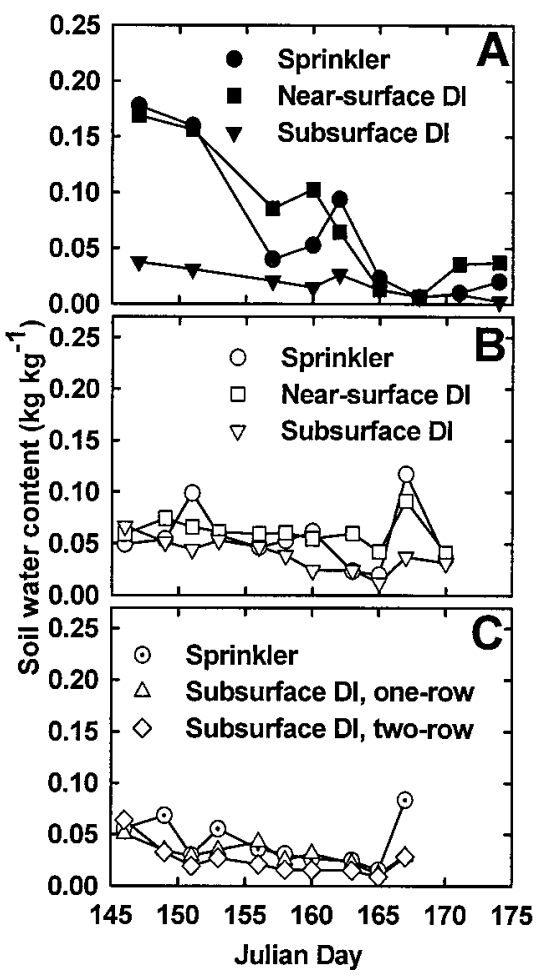

Fig. 1. Effect of irrigation method on soil water content at 0 - to $4-\mathrm{cm}$ depths in plant beds at Shafter during stem rot tests; A, 1994 small-plot experiment; B, 1995 small-plot experiment; and C, 1995 large-plot experiment. There were five to six replicate samples per data point, depending on experiment. In the small plots, drip irrigation (DI) lines were buried at 0 to $7 \mathrm{~cm}$ (near-surface DI) or $46 \mathrm{~cm}$ (subsurface DI) beneath the top of single-row beds. In the large plots, DI lines were $41 \mathrm{~cm}$ beneath the top of single-row or doublerow beds (subsurface DI, one-row; or subsurface DI, two-row; respectively). and 1995 large-plot tests ( $r=0.73$ to 0.83 , $P=0.0006$ to $<0.0001)$, but not within the 1995 small-plot test $(r=0.32, P=0.20)$; the correlation was significant for the pooled data from all three experiments ( $r=$ 0.67, $P<0.0001$; Fig. 2B). Similarly, the mean soil water contents were positively correlated with tuber infection severity scores in the 1994 small- and 1995 largeplot tests ( $r=0.66$ to $0.80 ; P=0.003$ to $0.0004)$, but not within the 1995 small-plot test $(r=0.29, P=0.24)$; the overall correlation was significant $(r=0.53, P<$ 0.0001; not plotted).

\section{DISCUSSION}

We determined that, in California's San Joaquin Valley, subsurface drip irrigation is less conducive than conventional sprinkler irrigation or near-surface drip irrigation to development of potato stem and

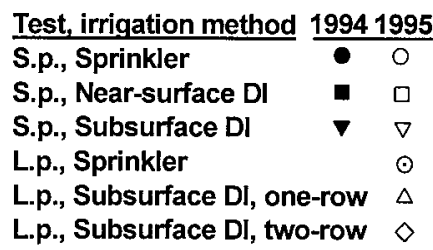

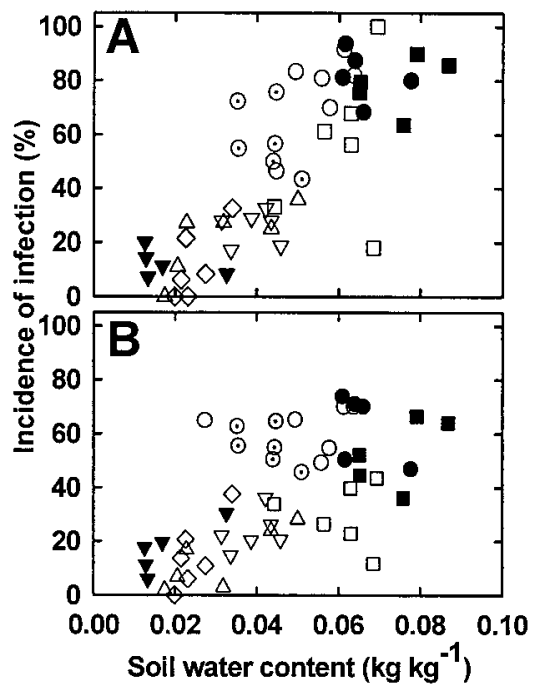

Fig. 2. Correlation of mean soil moisture contents at 0- to 4-cm depths in plant beds at Shafter with incidence of $\mathbf{A}$, stem infection $(r=0.82, \mathrm{P}$ $<0.0001)$ and $\mathbf{B}$, tuber infection $(\mathrm{r}=0.67, \mathrm{P}<$ $0.0001)$ by Sclerotium rolfsii. Each symbol indicates the values determined in one irrigation plot during a stem rot disease experiment. The soil water contents are averages based on two to three samples per week, taken during the period between soil infestation with S. rolfsii (at 5 to 6 weeks before harvest) and disease assessment at harvest; "S.p." and "L.p." indicate values from small- and large-plot experiments, respectively. In the small plots, drip irrigation (DI) lines were buried at 0 to $7 \mathrm{~cm}$ (near-surface DI) or $46 \mathrm{~cm}$ (subsurface DI) beneath the top of single-row beds. In the large plots, DI lines were $41 \mathrm{~cm}$ beneath the top of single-row or double-row beds (subsurface DI, one-row; or subsurface DI, tworow; respectively). tuber rot caused by $S$. rolfsii. Subsurface drip irrigation with lines buried at 41 or $46 \mathrm{~cm}$ of depth consistently resulted in less disease caused by $S$. rolfsii compared with the other irrigation methods. This finding compliments our previous report (10), which documented improved tuber yields and irrigation water savings with single-row subsurface drip irrigation compared with conventional sprinkler irrigation.

We also demonstrated feasibility and limitations of applying metam sodium through drip systems for preplant management of $S$. rolfsii. The sclerotia bioassay tests indicated that metam sodium applications through near-surface drip tape (Shafter) or surface drip tubing (Lamont) can effectively treat much of the soil that ultimately rests next to potato stems after planting. However, in soil naturally infested with $S$. rolfsii, potato planting operations can redistribute the pathogen after chemigation (i.e., conventional practices lift some soil from the furrow area onto the beds after planting). Therefore, without special precautions, inoculum redistribution after treatment could compromise the effectiveness of strip chemigations with metam sodium, such as those applied by drip at Shafter. Natural disease incidence in our trials was not sufficient to assess risk due to inoculum redistribution after chemigation. Our results clearly showed that metam sodium applications through widely spaced or deeply placed drip lines (as used for the double-row and 46-cm subsurface drip treatments, respectively) result in poor or inconsistent control of $S$. rolfsii sclerotia in upper parts of plant beds. Only drip tubing buried at least $41 \mathrm{~cm}$ was deep enough to escape mechanical damage by the potato digger at harvest, allowing use of the tubing for multiple seasons.

Previous reports have demonstrated important effects of irrigation method and drip line placement on incidence and severity of soilborne diseases of other crops. For example, subsurface drip irrigation reduced incidence of lettuce drop and kept inoculum density of Sclerotinia minor relatively low compared with furrow irrigation (29). With peppers, subsurface placement of drip lines reduced incidence and severity of Phytophthora root rot compared with placement of drip lines at the surface and near the plant row (7).

Drip treatments with metam sodium have produced mixed results in other cropping systems. For example, Roberts et al. (24) reported that drip application of metam sodium in strips on plant beds controlled Pythium ultimum, Fusarium sp., Meloidogyne incognita, and $M$. javanica on carrots and tomatoes. On the other hand, Fusarium crown and root rot on tomato was not controlled by preplant drip treatments with metam sodium, whether the applications were made before or after forming plant beds (17). 
In our experiments, effects of the application methods on efficacy of the metam sodium treatments were consistent with the biocide's known behavior in soil. Metam sodium does not diffuse far in vapor phase through soil, but it can be carried effectively in water solution through the soil $(13,16,28)$. In our tests, sclerotia of Sclerotium rolfsii tended to survive where the soil was not wetted by chemigation, as would be expected due to the limited movement of metam sodium in vapor phase. Field observations in the Shafter chemigation experiments indicated that the deep subsurface drip applications failed to wet much of the soil near the top of the beds or under the furrows. Conversely, the sprinkler applications in the same tests tended to run off plant beds and accumulate in furrows, and this apparently interfered with delivery of the biocide to sclerotia at the deep positions within the beds. The Shafter chemigations with near-surface drip tubing effectively reached all test depths below the lines, giving complete control of sclerotia located there. At Lamont, the relatively close spacing of drip emitters and the loose, flat soil surface improved uniformity of surface drip and sprinkler applications of metam sodium, as evidenced by the death of most test sclerotia at the $15-\mathrm{cm}$ depth.

Fumigants such as emulsified chloropicrin or chloropicrin/1,3-D mixtures may be more effective than metam sodium for treating plant beds using subsurface drip tubing. Recent research with strawberries demonstrated the utility of drip chemigation with the former two materials, which both have greater potential than metam sodium for vapor phase movement beyond the wetted zone after application by drip (2).

In the work reported here, relatively low incidence of stem infection caused by $S$. rolfsii was associated with relative dryness of the surface soil. Although the subsurface and near-surface drip plots were irrigated at the same frequency and with similar amounts of water, only the subsurface drip treatment, which resulted in relatively dry surface soil, had lower incidence of stem rot compared with that in sprinkler plots. These results are consistent with previous reports that moist conditions favor infection by $S$. rolfsii $(1,5,22,23,31)$. It is possible that additional factors other than surface soil water content affected tuber disease variables. For example, nearsurface drip and sprinkler irrigation resulted in similar surface soil water contents during stem rot experiments but, in 1995, tuber disease incidence and severity were lower with the former irrigation method than with the latter. Our data provided no evidence that the irrigation method effects on stem rot disease parameters were mediated through associated effects on soil temperature or the number of potato plants or tubers per plot. In the case of lettuce drop, disease suppression provided by subsurface drip irrigation compared with furrow irrigation was associated with surface-soil dryness (29), but there was no evidence for microbial mediation of the effect (4).

During the late spring and early summer, the arid climate of the southern San Joaquin Valley contributes greatly to the observed capability of subsurface drip to meet crop water needs while maintaining a relatively dry soil surface. During May and June, typical reference evapotranspiration for Shafter totals $360 \mathrm{~mm}$ (California Irrigation Management System, online averages for Shafter), but the area's average rainfall during the period is only $6 \mathrm{~mm}$ (30-year averages for Wasco, University of California Statewide Integrated Pest Management Project, online climatic averages). During this period, therefore, crop water use tends to result in a dry soil surface unless the ground is wet from above by irrigation, as occurs with sprinklers. Suppression of stem rot by subsurface drip irrigation may not occur in regions where rainfall frequently wets the soil surface during warm temperatures that are conducive to the disease. With stem rot on peanut, Davis et al. determined that irrigation increased area under the disease progress curve for aboveground stem lesions in a relatively dry year but not in a relatively wet year (8).

Many factors affect the economic utility of irrigation systems, including system and water costs, water availability, crop yield and value, crop rotations, and policies regulating chemigation. For potato, the higher initial expense of drip irrigation systems compared with sprinklers is an important factor. Nevertheless, at least some of the initial cost of drip systems can be offset by irrigation water savings and marketable yield increase (10), and we demonstrated, in the large-plot experiments, that subsurface drip tubing can be left in place for multiple potato crops, thereby further lessening the drip system cost burden. The results reported here indicate that, in the San Joaquin Valley, subsurface drip irrigation improves cultural management of stem rot disease while providing a means for partial preplant control of the pathogen using chemigation. The information should aid future assessments of drip systems for potato and its rotation crops.

\section{ACKNOWLEDGMENTS}

We thank J. E. Ayars for nutritional analyses, M. V. McKenry for assistance in the Lamont experiment, and B. E. Mackey for statistical advice.

\section{LITERATURE CITED}

1. Abeygunawardena, D. V. W., and Wood, R. K. S. 1957. Factors affecting the germination of sclerotia and mycelial growth of Sclerotium rolfsii Sacc. Trans. Br. Mycol. Soc. 40:221231.

2. Ajwa, H. A., Trout, T. J., Mueller, J. P., Wilhelm, S., Nelson, S. D., Soppe, R., and
Shatley, D. Application of alternative fumigants through drip irrigation systems. Phytopathology. In press.

3. Awari, H. W., and Hiwase, S. S. 1994. Effect of irrigation systems on growth and yield of potato. Ann. Plant Physiol. 8:185-187.

4. Bell, A. A., Liu, L., Reidy, B., Davis, R. M., and Subarrao, K. V. 1998. Mechanisms of subsurface drip irrigation-mediated suppression of lettuce drop caused by Sclerotinia minor. Phytopathology 88:252-259.

5. Beute, M. K., and Rodriguez-Kabana, R. 1979. Effect of wetting and the presence of peanut tissues on germination of sclerotia of Sclerotium rolfsii produced in soil. Phytopathology 69:869-872.

6. Browne, G. T., DeTar, W. R., and McKenry, M. V. 1996. Comparative severity and management of late blight, southern blight, and root knot nematodes on potato with drip and sprinkler systems. (Abstr.) Phytopathology 86:S93.

7. Café, A. C., and Duniway, J. M. 1996. Effect of location of drip irrigation emitters and position of Phytophthora capsici infections in roots on Phytophthora root rot of pepper. Phytopathology 86:1364-1369.

8. Davis, R. F., Smith, F. D., Brenneman, T. B., and McLean, H. 1996. Effect of irrigation on expression of stem rot of peanut and comparison of aboveground and belowground disease ratings. Plant Dis. 80:1155-1159.

9. de Icochea, T. A. 1981. Stem rot. Pages 50-51 in: Compendium of Potato Diseases. W. J. Hooker, ed. American Phytopathological Society, St. Paul., MN.

10. DeTar, W. R., Browne, G. T., Phene, C. J., and Sanden, B. M. 1996. Real-time irrigation scheduling of potatoes with sprinkler and subsurface drip systems. Pages 812-824 in: Proc. Int. Conf. Evapotransp. Irrig. Sched. Am. Soc. Agric. Eng. St. Joseph, MI.

11. DeTar, W. R., Kiber, D. F., Grenoble, D. W., and Daniels, R. 1983. Trickle irrigation vs. no-irrigation of five horticultural crops in Pennsylvania. Trans. Am. Soc. Agric. Eng. 26:82-86.

12. Foti, S, Mauromicale, G., and Ierna, A. 1995. Influence of irrigation regimes on growth and yield of potato cv. Spunta. Potato Res. 38:307-318.

13. Gerstl, Z., Mingelgrin, U., Krikum, J., and Yaron, B. 1977. Behavior and effectiveness of vapam applied to soil in irrigation water. Pages 42-50 in: Behavior of Pesticides in Soil. M. Horowitz, ed. Proc. Israel-France Symp. 1975. Agric. Res. Organ. Bet Dagan Spec. Publ. 82.

14. Hartz, T. K. 1993. Drip-irrigation scheduling for fresh-market tomato production. HortScience 28:35-37.

15. Heerman, D. F., Wallender, W. W., and Bos, M. G. 1990. Irrigation efficiency and uniformity. Pages 125-149 in: Management of Farm Irrigation Systems. G. J. Hoffman, T. A. Howell, and K. H. Solomon, eds. Am. Soc. Agric. Eng. Monogr. 9.

16. Leistra, M., Smelt, J. H., and Nollen, H. M. 1974. Concentration-time relationships for methyl isothiocyanate in soil after injection of metam-sodium. Pestic. Sci. 5:409-417.

17. McGovern, R. J., Vavrina, C. S., Nohling, J. W., Datnoff, L. A., and Yonce, H. D. 1998 Evaluation of application methods of metam sodium for management of Fusarium crown and root rot in tomato in southwest Florida. Plant Dis. 82:919-923.

18. Mitchell, J. P., Allaire-Leung, S. E., Sanden, B. L., and $\mathrm{Wu}$, L. 2000. Sprinkler spacing does not affect carrot yield and quality. Horttechnology 10:370-373.

19. Neibling, H., and Brooks, R. 1995. Potato production using subsurface drip irrigation- 
water and nitrogen management. Pages 656663 in: Microirrigation for a Changing World: Conserving Resources/Preserving the Environment. Proc. Fifth. Int. Microirrig. Congr. Am. Soc. Agric. Eng. St. Joseph, MI.

20. Phene, C. J. 1995. The sustainability and potential of subsurface drip irrigation. Pages 359-367 in: Microirrigation for a Changing World: Conserving Resources/Preserving the Environment. Proc. Fifth. Int. Microirrig. Congr. Am. Soc. Agric. Eng. St. Joseph, MI.

21. Phene, C. J., and Sanders, D. C. 1976. Influence of combined row spacing and high frequency trickle irrigation on production and quality of potatoes. Agron. J. 68:602-607.

22. Porter, D. M., Smith, D. H., and RodriguezKabana, R. 1982. Peanut plant diseases. Pages 326-410 in: Peanut Science Technology. H. E. Patee and C. T. Young, eds. American Peanut Research and Education Society, Yaokum, TX.
23. Punja, Z. K., and Jenkins, S. F. 1984. Influence of temperature, moisture, modified gaseous atmosphere, and depth in soil on eruptive sclerotial germination of Sclerotium rolfsii. Phytopathology 74:749-754.

24. Roberts, P. A., Magyarosy, A. C., Matthews, W. C., and May, D. M. 1988. Effects of metam sodium applied by drip irrigation on root-knot nematodes, Pythium ultimum, and Fusarium sp. in soil and on carrot. Plant Dis. 72:213-217.

25. Sammis, T. W. 1980. Comparison of sprinkler, trickle, subsurface, and furrow irrigation of row crops. Agron. J. 72:701-704.

26. Scherm, H., and van Bruggen, A. H. C. 1995. Comparative study of microclimate and downy mildew development in subsurface drip- and furrow-irrigated lettuce fields in California. Plant Dis. 79:620-625.

27. Shalhevet, J., Shimshi, D., and Meir, T. 1983.
Potato irrigation requirements in a hot climate using sprinkler and drip methods. Agron. J. 75:13-16.

28. Smelt, J. H., and Leistra, M. 1974. Conversion of metam sodium to methyl isothiocyanate and basic data on the behavior of methyl isothiocyanate in soil. Pestic. Sci. 5:401-407.

29. Subarrao, K. V., Hubbard, J. C, and Schulbach K. F. 1997. Comparison of lettuce diseases and yield under subsurface drip and furrow irrigation. Phytopathology 87:877-883.

30. University of California Statewide IPM Project. 1986. Integrated Pest Management for Potatoes in the Western United States. Publication 3316. Univ. Calif. Div. Agric. Nat. Resour. Oakland, CA.

31. Watkins, G. M. 1961. Physiology of Sclerotium rolfsii, with emphasis on parasitism Phytopathology 51:110-113. 